\title{
Alumni Reflections on Gender Equality in the ICT Context
}

\author{
Eija Koskivaara $^{1(\bowtie)}$ (D) and Brita Somerkoski ${ }^{2}$ (D) \\ 1 Turku School of Economics, University of Turku (Turun yliopisto), \\ 20014 Turku, Finland \\ eija.koskivaara@utu.fi \\ 2 Department of Teacher Education, University of Turku (Turun yliopisto), \\ 20014 Turku, Finland
}

\begin{abstract}
This study aims to bridge the digital gender divide in information and communication technology (ICT) education and field by reflecting the alumni opinions on gender equality in the ICT context. The study aims to raise the awareness of gender equality issues through the work-life reflections. This is done to understand better the gender equality issue, and to give proposals to promoting equality also for the faculty members who teach ICT related subjects in the university. The data for the study was collected from $131(\mathrm{n}=131)$ ICT alumni that represent 25 nationalities. Results reveal that men with $77 \%$ share dominate the closest supervisor positions and $14 \%$ of the previous ICT students in the university have felt some kind of gender-based discrimination in their work. The data-driven content analysis was used to analyze the data. In the analysis we found five main categories behind the gender-based discrimination: society, organizational; individual action; hard facts and zero. We argue, that society, organizational, and individual action proposals illustrate the digital transformation process.
\end{abstract}

Keywords: Information technology $\cdot$ Digital gender divide $\cdot$ Equality

\section{Introduction}

Nelson Mandela [1] said: "Education is the most powerful weapon which we can use - which we can use in order to prepare our youth for their role as leaders of tomorrow." One success story of the power of education comes from Finland, where free education and equal access to education is a constitutional right [2] and where 15 year old students have performed very well in the OECD Programme for International Student Assessments (PISA) [3].

Today, another powerful weapon to change the world is digital transformation or digitalization. The digital transformation may be categorized into three dimensions: the use of new digital technologies; the change of organizational processes or the creation of new business models; and influencing all aspects of human life [4]. The digital transformation has changed the phenomenon of the digital divide from a situation of access to acquiring sufficient skills to use information and communication technology (ICT) effectively [5, 6]. Based on the latest OECD report [7], digitalization, ICT and 
technical skills development are seen as key components for human well-being and social development. Nevertheless, a gender gap in the access, use, and ownership of digital transformation is still present in G20 economies [7]. This gap is defined as the digital gender divide. Based on the findings of OECD, the digitalization and fighting the digital gender divide offers opportunities, enhances women empowerment and holds promises for enhanced productivity growth. The digital gender divide is well recognized at the work-life balance: Women and girls with poor digital literacy skills will struggle to find jobs as technology advances and this is an urgent global problem [8]. It is argued that girls are less confident in their maths, science and IT abilities, often due to or fueled by societal and parental biases, and parents' expectations about the future of their teenagers by leading girls' lower engagement in science and ICTs [9]. The effective promotion of women's digital adoption from the government, from the private sector and the civil society is proposed as one solution [10]. However, this is not enough. Also educational elements in fighting against the digital gender divide are needed. It is essential to understand the work-life reflections to be able to develop education. This paper aims to research the perceptions and reflections on gender equality in the context of ICT.

Since 1979, it has been possible to study Information System Science (ISS) as a major subject at the Turku School of Economics (TSE) in the University of Turku. During these 40 years there has been 580 graduates of which $36 \%$ are women. The percentage of female graduates has been slightly diminishing; from the $1980 \mathrm{~s} 48 \%$, 1990 s $33 \%$, after that stayed at that level for the next two decades $-34 \%$ for the 2000 and $36 \%$ for the 2010s [11]. Unfortunately, this finding supports the northern genderequality paradox in STEM (science, technology, engineering, mathematics) education: Based on that idea the more equal the society, the fewer women are doing the STEM education [12].

The concept of co-creation and acting together with work-life is proposed to be one solution for developing ICT education [13]. In the universities, alumni surveys are frequently used to get feedback about employability and employment. ISS subject/institute has been running alumni surveys regularly to get feedback on the ICT knowledge and skill requirements of the employers. Therefore, one purpose to carry out an alumni survey is to support the employability of graduates by improving the curriculum of the university according to the industry requirements. The latest alumni survey was carried out in the spring 2019 and it included equality related questions. In this case study, we are analyzing these alumni responses and proposals against inequality. The research question of this study is: What are the alumni experiences and perceptions towards equality in work in the context of ICT? Furthermore, we are interested in what proposals alumni will give to change the situation in the ICT context.

\section{Data Collection and Analysis}

The data for the study was collected with the alumni questionnaire (AQ). It was originally established to tighten the relationship with the ICT alumni, to enhance the work-life connections with the studies and to engage the alumni with the faculty activities such as guest lecturers, visits and practical training opportunities. The faculty 
has been involved with a Horizon 2020 project concerning gender equality issues in the context of ICT. Based on this activity we added some gender equality questions to the AQ.

The current AQ was pilot-tested with the faculty members and researchers. The questionnaire was designed is such a way that privacy issues and the European GDPR regulations were taken into account. We collected and analyzed the answers anonymously. The final AQ has 40 questions and we sent the questionnaire to 381 alumnus whose email is in a voluntary database of the alumnus. 91 emails were not responding. The online survey was distributed also via the social media channels of international alumni network.

Altogether $131(\mathrm{n}=131)$ alumni representing 25 nationalities replied, of these $28 \%$ were women. In this study, we analyzed two quantitative questions for background purposes. These questions were about the gender of the closest supervisor (131 responses) and whether responders have felt any gender-based discrimination in their work (131 responses).

For the qualitative data of equality in work (51 open responses $37 \%$ women), we used the content-based thematic analysis with three iterations by reading the texts many times. The meaning units (hits) were collected in a matrix and encoded. The meaning units were labeled based on text content. Content analysis and the matrix were used to provide replicable and valid inferences about gender equality. To secure reliability, two researchers were analyzing the hits and categorizing them. After many overlaps, typical for this kind of research design, the content was organized under themes with lower and upper categories. Based on the text analysis we formulated 16 sub-categories, which were grouped into five super-categories and further conceptualized to theory with three main categories.

\section{Results}

The quantitative gender bias fact is that men dominate as their closest supervisor with $77 \%$. Table 1 shows the overall gender distribution of the closest supervisors.

Table 1. Gender of closest supervisor.

\begin{tabular}{l|r|c}
\hline Gender & N & Percent \\
\hline Men & 101 & 77,1 \\
\hline Women & 24 & 18,32 \\
\hline Other & 2 & 1,53 \\
\hline I do not want to say, or I do not know & 4 & 3,05 \\
\hline
\end{tabular}

$14 \%$ of alumnus have felt some kind of gender-based discrimination in their work (Table 2). The answers were based on their last five year working experience. About seven percent think that the promotion or higher salary was given to the other less qualified gender. Eight people mentioned the following reasons when we asked a description of the unfair situations. The reasons are related to age, management, gender, and country: 
- "Based on age, I've been treated as too young not based on my experience and skills." (R97)

- "Age discrimination" (R30)

- "Actually I think few people should have deserved a promotion, but were not give one." (R31)

- "More like Nepotism" (R37)

- "I never experienced any gender-based discrimination in Finland. Currently I work in a big global company in the other country and here I sometimes feel that my men colleagues threat me like their secretary." (R116)

- "One firm did not grant a loan and I felt very strongly it would have been granted if I were a man. Seriously." (R114)

- "Men are always preferred for the most interesting work, while women are mostly used for their organizational skills" (R129)

Table 2. Gender-based discrimination at work.

\begin{tabular}{l|r|c}
\hline & $\mathrm{N}$ & Percent \\
\hline No kind of gender-based discrimination in their work & 111 & 84,73 \\
\hline $\begin{array}{l}\text { Yes, some kind of gender-based discrimination in their work } \\
\begin{array}{l}\text { Somebody, other gender than me got the work although I was more } \\
\text { qualified }\end{array}\end{array}$ & 5 & 14,62 \\
\hline $\begin{array}{l}\text { Somebody, other gender than me got the promotion or salary prize } \\
\text { although I was more qualified }\end{array}$ & 4 & 3,05 \\
\hline $\begin{array}{l}\text { I was treated unfairly for another reason. How? Describe the situation } \\
\text { shortly }\end{array}$ & 8 & 6,11 \\
\hline I do not want to say & 2 & 1,53 \\
\hline
\end{tabular}

We asked our alumni "If you feel that the equality in the IT/IS field/education could be better, do you have any proposal on how to change the situation?" 51 alumni responded ( $\mathrm{f}=51$ ) to the question that equality in the IT/IS field/education could be better. We asked the respondents to give proposals on how to change the situation.

In the thematic content analysis, we made the following iterations:

- $1^{\text {st }}$ iteration (analyzing text meanings): 16 categories (no opinion, zero, general awareness, raising awareness, content development, work-life connections, identity support, social competence, age, national identity, the state of art/more women)

- $2^{\text {nd }}$ iteration (grouped into super-categories): 5 categories (zero, awareness-raising, education and work-life connection development, soft skills, hard facts)

- $3^{\text {rd }}$ iteration (conceptualizing categories to theory): 3 main categories (0-category, digital transformation-category with three dimensions: individual, organizational and societal dimension, hard facts-category)

Conceptualized categories and their hits:

- Zero-category: no problem, no opinion: 21 hits 
- Digital transformation-category: societal awareness (10 hits), organizational (education) development (12 hits), individual development (7 hits): 29 hits

- Hard facts-category: age (4), nationality (3), more women (5): 12 hits

To better understand the issue we provide some examples of the responses. Firstly, the respondents suggested that companies should provide general awareness of the work tasks and especially whether the work is suitable for both genders. "Stats regarding the recruiting processes be open in a way that it's possible to recognize companies who avoid hiring women that are in a certain age (Man 9)". Also, some of the respondents pointed out that all the students should get more education on programming "More focus on specialization skills so that students know how a real business works to manage their IT (Woman 22)." Secondly, there should be enough connections to work-life and handson training. "More practical education (Woman 2)." Some respondents answered that the students need more teaching of social skills and support for professional identity. "More project management skills and tools; Purchasing negotiation skills; Emotional IQ skills (understanding others); Influencing people; Presentation and performing skills (Man 24)."

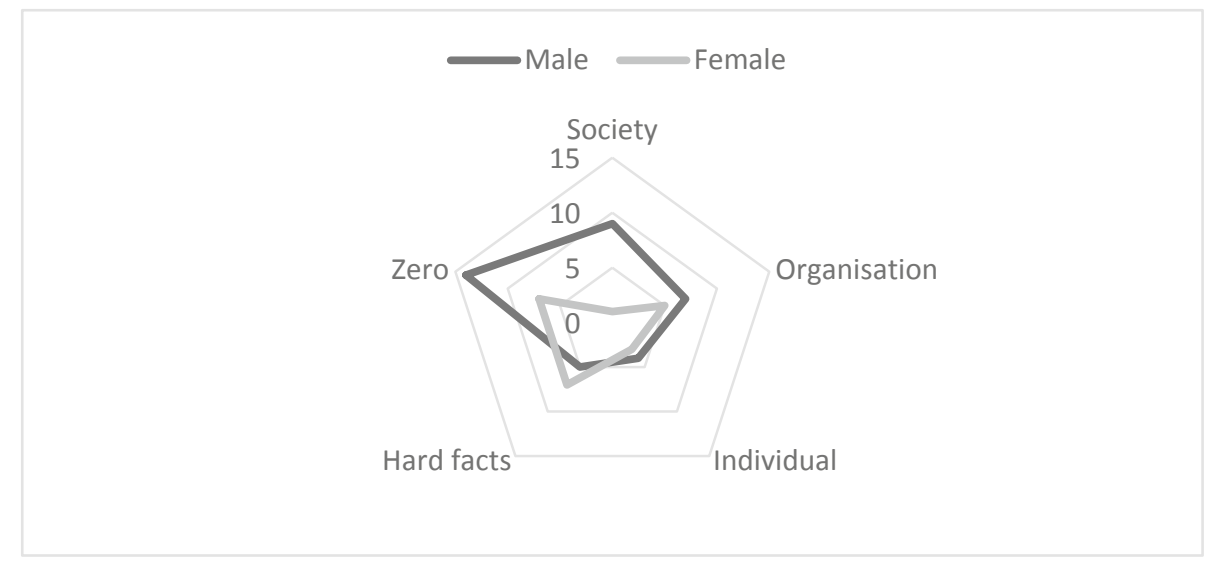

Fig. 1. Differences between male and female proposals for changing the inequality in the ICT education and field.

In Fig. 1, we are illustrating the inequality proposals and the levels between men and women. Men dominate the proposals $14>7$ that there are no actions needed to change the inequality situation. An example of men's proposal: "I guess this means equality between male and female? I believe that women selecting career within IT/IS, have excellent opportunities to be successful. Now gender equality is such a topic that all companies take this issue seriously. The biggest challenge is to increase the amount of female workers in IT/IS clusters. That is growing all the time, the challenge is to communicate women, what kind of career opportunities there are, and maybe to help them to understand that IS/IT positions are not necessarily very technology focused (which I believe is one main barrier to women) (Man 42)." But at the same time, men 
also dominate society based actions $9>1$ to be taken to change the situation. Individual action proposals are more or less at the same level. An example of woman proposal: "I think it would be important to support the development of professional identity of all the students, but perhaps women need to be focused particularly, at least as long as there is a lack of role models for women. You could ask all the students how confident they are as ISS professionals, and how their confidence could be further enhanced, and make gender analysis of the results, too (Woman 12)."

Altogether, men gave 21 proposals and women nine proposals related to digital transformation and gender inequality. As men dominates the number of the proposals it is also interesting to see the shape of the figure. Women seem to be more sensitive to identify the hard facts such as gender, age and nationality $(7>5)$ than men.

\section{Discussion}

To be able to develop and better understand the ICT education we researched the worklife reflections of the ICT alumni. All the results are based on the responses for the alumni survey $(\mathrm{n}=131)$.

It seems that men dominate the closest supervisor status - only $19 \%$ of the respondents had women supervisors. Most of the respondents did not experience any kind of discrimination in their work yet $14 \%$ did. The most common form of discrimination was gender-based, but also nationality and age-based forms of discrimination were reported.

However, alumni seem to be ready to change the situation and they gave several proposals for changing the situation in the future. The development proposals could be categories based on the current definition of digital transformation, i.e. some proposals were society level whereas others where either organizational or individual level. The respondents stated that we should approach the inequality questions to change the same procedures at the workplaces, such as making the recruiting more transparent and providing support in the identity building. In the context of education, the respondents stated that the students should get teaching in both the technical and social skills. Based on this paper and the alumni survey results our university should still continue the activities that connect the work-life and the university as this was seen as a good way for fighting inequalities.

Our alumni research reveals that our graduates have both faced and recognized gender inequality in the work-life and they are willing to change it. These findings are important as high equality and free education in the society do not guarantee gender equality in the ICT field. Digitalization is the most powerful weapon which we can use to change the world and to create a new kind of future. No society, nowhere in the world, does afford to create the digital future under the gender bias, which today is an undesirable situation globally. 
To summarise, with this study we are:

1. Illuminating the extent of male domination in the ICT workforce

2. Calling for recruitment to be transparent

3. Calling for support in identity building and

4. Highlighting the need for students to attain both technical and social skills.

\section{References}

1. Nelson Mandela speech at the Madison Park High School in Roxbury, Boston, 23 June 1990, 9.21/14.47. https://www.youtube.com/watch?v=b66c6OkMZGw

2. Dickinson, K.: How does Finland's top-ranking education system work? (2019). https:// bigthink.com/politics-current-affairs/how-finlands-education-system-works

3. PISA: What is PISA? (2019). http://www.oecd.org/pisa/

4. Reis, J., Amorim, M., Melão, N., Matos, P.: Digital transformation: a literature review and guidelines for future research. In: Rocha, Á., Adeli, H., Reis, L.P., Costanzo, S. (eds.) WorldCIST 2018. AISC, vol. 745, pp. 411-421. Springer, Cham (2018). https://doi.org/10. 1007/978-3-319-77703-0_41

5. Becking, S.K., Grady, M.L.: Contemporary Issues in Educational Leadership, 1:5 (2019). http://digitalcommons.unl.edu/ciel/. https://doi.org/10.32873/unl.dc.ciel.1011. ISSN 24729744

6. Van Deursen, A., van Dijk, J.: Toward a multifaceted model of internet access for understanding digital divides: an empirical investigation. Inf. Soc. 3, 379-391 (2015)

7. OECD: Bridging the digital gender divide (2018). http://www.oecd.org/internet/bridgingthe-digital-gender-divide.pdf

8. Taylor, L.: As technology advances, women are left behind in digital divide, Reuters, Big Story 10 (2018). https://www.reuters.com/article/us-britain-women-digital/as-technologyadvances-women-are-left-behind-in-digital-divide-idUSKBN1K02NT

9. OECD: The ABC of Gender Equality in Education: Aptitude, Behaviour, Confidence, PISA. OECD Publishing (2015). http://dx.doi.org/10.1787/9789264229945-en

10. Mariscal, J., Mayne, G., Aneja, U., Sorgner, A.: Bridging the gender digital gap. Econ. Open-Access Open-Assess. E-J. 13(2019-9), 1-12 (2019). https://doi.org/10.5018/ economics-ejournal.ja.2019-9

11. Koskivaara, E.: Finnish paradox of IS graduates. In: Proceedings of 25th American Conference of Information Systems (2019). ISBN 978-0-9966831-8-0

12. Stoet, G., Geary, D.C.: The gender-equality paradox in science, technology, engineering, and mathematics education. Psychol. Sci. 29(4), 581-593 (2018)

13. Aho, A.M., Sinclair, J.: Co-creation workshops for work life oriented ICT education. In: Uden, L., Liberona, D., Sanchez, G., Rodríguez-González, S. (eds.) LTEC 2019. CCIS, vol. 1011, pp. 302-312. Springer, Cham (2019). https://doi.org/10.1007/978-3-030-20798-4_26 